\title{
Faktor faktor yang mempengaruhi turnover intention karyawan di Kota Batam
}

\author{
Nanda Harry Mardika ${ }^{1 *}$; Argo Putra Prima² \\ ${ }^{1}$ Program Studi Manajemen, Universitas Putera Batam \\ ${ }^{2}$ Program Studi Akuntansi, Universitas Putera Batam \\ *E-mail korespodensi: mardikanandaharry@ymail.com
}

\begin{abstract}
This study aims to examine the factors that influence employee turnover intention in Batam City. The problem factor is job stress and job satisfaction. The purpose of this study was to determine the effect of job stress and job satisfaction on employee turnover intention partially and simultaneously. The total sample of 96 respondents was taken using a purposive sampling method and then the data were analyzed by using the SPSS program. The methodology in this research is descriptive with a quantitative approach. The results showed that work stress partially had a positive and significant effect on employee turnover intention with a $t$ value of 3.532 and $a$ significant value of 0.001. Job satisfaction partially has a negative and significant effect on employee turnover intention with a t value of -2.509 and a significant value of 0.014. Simultaneously this study shows that job stress and job satisfaction have a positive and significant effect on employee turnover intentions with an at-count value of 13.213 and a significant value of 0.000. The coefficient of determination of the two independent variables together on the dependent variable is $22.1 \%$ and $77.9 \%$ is influenced by other variables not examined in this study.
\end{abstract}

Keywords: Job stress, Job satisfaction;Turnover intention.

\begin{abstract}
Abstrak
Penelitian ini bertujuan untuk menguji faktor-faktor yang mempengaruhi turnover intention karyawan di Kota Batam. Faktor yang menjadi masalah adalah stres kerja dan kepuasan kerja. Tujuan penelitian ini adalah untuk mengetahui pengaruh stres kerja dan kepuasan kerja terhadap turnover intention karyawan secara parsial dan juga simultan. Jumlah Sampel sebanyak 96 responden yang diambil dengan menggunakan metode purposive sampling dan kemudian data dianalisis dengan Program SPSS. Metodologi dalam penelitian ini adalah deskriptif dengan pendekatan kuantitatif. Hasil penelitian menunjukkan bahwa stres kerja secara parsial berpengaruh positif dan signifikan terhadap turnover intention karyawan dengan nilai t hitung 3,532 dan nilai signifikan 0,001. Kepuasan kerja secara parsial berpengaruh negatif dan signifikan terhadap intensi turnover karyawan dengan nilai t -2.509 dan nilai signifikan 0,014. Secara simultan penelitian ini menunjukkan bahwa stres kerja dan kepuasan kerja berpengaruh positif dan signifikan terhadap intensi turnover karyawan dengan nilai $\mathrm{t}$ hitung 13,213 dan nilai signifikan 0,000. Koefesien determinasi dari dua variabel independen secara bersama-sama terhadap variabel dependen yaitu 22,1\% dan 77,9\% dipengaruhi oleh variabel lain yang tidak diteliti dalam penelitian ini.
\end{abstract}

Kata kunci: Stres kerja; Kepuasan kerja; Turnover intention. 


\section{PENDAHULUAN}

Kota Batam merupakan kota industri yang di harapkan bisa mengembangkan perekonomian masyarakat kota batam dan umumnya bagi Negara Kesatuan Republik Indonesia. Dari pengembangan industri yang dilakukan, diharapkan dapat menyerap banyak tenaga kerja dan mampu memberikan keamanan dalam bekerja bagi karyawan dan kesejahteraan dalam kehidupan perekonomian. Namun hal tersebut belum sepenuhnya dapat dilakukan mengingat susahnya memperoleh lapangan kerja di kota Batam. Selain susahnya mendapat pekerjaan, fenomena lain yang juga mengikuti masalah tersebut adalah Turnover Intention yang muncul di dunia pekerjaan bagi yang sedang bekerja. Tingginya Tingkat Turnover Intention karyawan di kota batam disebabkan oleh beberapa faktor. Berdasarkan hasil wawancara yang sudah dilakukan ke beberapa pekerja di kota batam, diantaranya adalah faktor stres kerja baik menyangkut target kerja maupun waktu kerja yang bisa saja lebih panjang rentang waktunya dikarenakan beberapa perusahaan ada yang beroperasi 24 jam dalam sehari. Selain target kerja, kepuasan kerja karyawan dinyalir bisa mempengaruhi Turnover Intention karyawan di kota batam. Tidak puasnya karyawan dengan kompensasi yang diterima, sikap atasan maupun kesesuaian pekerjaan yang diberikan dengan kualifikasi pendididkan dan harapan, menjadi penyebab munculnya Turnover Intention. Berdasarkan fenomena tersebut, maka penulis tertarik untuk melakukan penelitian dengan judul: Faktor faktor yang mempengaruhi turnover intention karyawan di kota Batam. Adapun tujuan dari penelitian ini adalah: 1).Untuk mengetahui pengaruh stres kerja terhadap Turnover Intention karyawan di kota Batam. 2).Untuk mengetahui pengaruh Kepuasan Kerja terhadap Turnover Intention karyawan di kota Batam. 3).Untuk mengetahui pengaruh Stres Keerja dan Kepuasan kerja secara simultan terhadap Turnover Intention karyawan di kota Batam.

\section{KAJIAN PUSTAKA}

\section{Turnover Intention}

Turnover intention (keinginan berpindah kerja) merupakan kecenderungan atau intensitas individu untuk meninggalkan organisasi dengan berbagai alasan dan diantaranya keinginan untuk mendapatkan pekerjaan yang lebih baik (Ronald dan Milkha, 2014). Penelitian ini mengadopsi dimensi yang digunakan oleh Abelson dalam Sumarto (2009) untuk mengukur turnover intention yang terdiri dari: 1).Pemikiran untuk berhenti (Thinking of quitting ) 2).Niat untuk mencari (Intent to search ). 3). Kemungkinan menemukan suatu pekerjaan yang dapat diterima oleh pemberi kerja lain (Probability of finding an acceptable job with another employer). 4). Niat untuk meninggalkan pekerjaan (intent to leave)

\section{Kepuasan kerja}

Definisi komprehensif bahwa kepuasan kerja meliputi reaksi atau sikap kognitif, afektif, dan evaluatif. Jadi kepuasan kerja merupakan kondisi emosi yang senang atau emosi positif yang berasal dari penilaian pekerjaan atau pengalaman kerja seseorang. Hal ini bisa dikatakan sebagai persepsi karyawan mengenai seberapa baik pekerjaan mereka memberikan hal yang dinilai penting (Luthans dalam Kaswan, 2012). Locke dalam Turkyilmas (2009),kepuasan kerja merupakan pernyataan emosi yang positif sebagai hasil dari pengakuan terhadap pekerjaan atau pengalaman dalam bekerja. Indikator yang digunakan dalam pengukuran variabel kepuasan kerja adalah: 1).Pekerjaan itu sendiri (Work itself), 2).Gaji (Pay), 3).Supervisi, 4).Hubungan dengan teman sekerja (Co-workers), 4).Kesempatan promosi (Promotion opportunities) 


\section{Stres kerja}

Stres kerja merupakan salah satu hal penting yang perlu diperhatikan dalam pengelolaan sumberdaya manusia di perusahaan.Stres didefinisikan sebagai kondisi yang muncul pada diri seseorang akibat tekanan yang berasal dari tuntutan yang tinggi di lingkungan sekitarnya yang menyebabkan dampak buruk bagi dirinya (Mulyadi, 2015; Robbins dan Judge, 2013). Menurut Sopiah (2008: 89) stres kerja karyawan dapat dilihat dalam tiga aspek, yaitu: 1).Gejala psikologis dengan indikator : Sikap apatis terhadap pekerjaan, luapan emosional, komunikasi tidak efektif, merasa tersaingi, kebosanan, ketidakpuasan kerja, kehilangan daya konsentrasi dan problem tidur. 2).Gejala fisik dengan indikator : mudah lelah dan menunda pekerjaan atau tugas. 3).Gejala prilaku dengan indikator : menurunnya produktivitas, meningkatnya penggunaan obat-obatan dan meningkatnya prilaku absensi

\section{Penelitian terdahulu}

Adapun penelitian terdahulu yang dijadikan referensi penelitian ini adalah Penelitian yang dilakukan oleh Tnay et al. (2013) The influences of job satisfaction and organizational commitment on turnover intention yang menyatakan hasil penelitian bahwa Terdapat pengaruh signifikan kepuasan pada gaji terhadap Turnover Intention. PenelitianJaved et al. (2014) dengan judul Effect of Role Conflict, Work Life Balance and Job Stress on Turnover Intention: Evidence from Pakistan Juga menyebutkan bahwa stress kerja berpengaruh positif dan signifikan terhadap Turnover Intention. Penelitian lainnya adalah penelitian yang dilkukan oleh Gama Dwi Syafrizal (2011) yang berjudul analisis pengaruh kepuasan kerja terhadap turnover intention serta dampaknya terhadap kinerja karyawan membuktikan bahwa variabel kepuasan kerja berpengaruh negatif terhadap turnover intention, turnoverintention berpengaruh negatif terhadap kinerja karyawan, kepuasan kerja berpengaruh positif terhadap kinerja karyawan dan variabel turnover intention mampu menjadi variabel intervening antara kepuasan kerja terhadap kinerja karyawan. Peneliti lainnya adalah Syahronica (2015) dengan Judul Pengaruh Kepuasan Kerja Dan Stres Kerja Terhadap Turnover Intention (Studi Pada Karyawan Departemen Dunia Fantasi PT Pembangunan Jaya Ancol, Tbk) membuktikan bahwa variabel bebas mempunyai pengaruh yang signifikan terhadap turnover intention secara simultan dan parsial.

\section{METODE}

Metode penelitian ini menggunakan metode deskriptif kuantitatif dengan pendekatan kuantitatif. Data diperoleh dengan menggunakan kuesioner dan di oleh dengan program SPSS.

\section{Populasi dan sampel}

Populasi penelitian ini adalah seluruh karyawan perusahaan yang bekerja di Kota Batam.Teknik pengambilan sampel menggunakan metode purposive sampling yaituKaryawan yang Bekerja dengan Sistem Shift Kerja di Kota Batam. Karena jumlah karyawan yang bekerja di perusahaan dengan jam masuk Shifting tidak diketahui, maka digunakan rumus Lemeshow sebagai formula perhitungan penarikan sampel yang kemudian di dapatkan jumlah sample sebanyak 96 orang.

\section{Teknik pengumpulan data}

\section{Kuesioner (angket)}

Menurut Sugiyono (2014: 142) Kuesioner adalah teknik pengumpulan data yang dilakukan dengan cara memberi seperangkat pertanyaan atau pernyataan tertulis kepada 
responden untuk dijawab dengan di ukur berdasarkan skala Likert yang menggunakan 5 angka predikat.

\section{Uji kualitas instrumen}

Uji validitas

Uji Validitas membandingkan perhitungan nilai korelasi product moment $(\mathrm{r}$ hitung) terhadap nilai $r$ tabel. Nilai $r$ tabel dihitung untuk $\alpha=0,05$ dan derajat kebebasan $(\mathrm{dk}=\mathrm{n}-2)$ dengan kaidah keputusan sebagai berikut: 1).Jika rhitung $>\mathrm{r}$ table berarti valid. 2).Jika rhitung $<\mathrm{r}$ table berarti tidak valid.

\section{Uji reliabilitas}

Kriteria untuk mengetahui diterima atau tidaknya suatu data reliabel atau tidak jika; nilai alpha >nilai kritis product moment, atau nilai $\mathrm{r}_{\text {tabel. }}$. Dapat pula dilihat dengan menggunakan nilai batasan penentu, yaitu 0.6.

\section{Uji asumsi klasik}

\section{Uji normalitas}

Pengujian normalitas dalam penelitian ini yang pertama menggunakan histogram regression residual yang sudah distandarkan, pada histogram ini nilai residu yang berdistribusi normal akan digambarkan membentuk lonceng atau bell shaped.

\section{Uji multikolinieritas}

Untuk mendeteksinya dengan cara menganalisis nilai toleransi dariVariance Inflation Factor (VIF).Apabila terjadi korelasi, maka dinamakan terdapat problem multikolinearitas.Untuk mendeteksi ada atau tidaknya multikolinieritas di dalam model regresi adalah dengan melihat nilai significance (2-tailed), jika nilai VIF>10 maka terdapat gejala multikolinieritas.

\section{Uji heteroskedastisitas}

untuk melihat terjadi atau tidaknya Heterokedastisitas adalah dengan menggunakan metode grafik yaitu dengan melihat pola titik-titik pada scatterplot regresi, jika titik-titik menyebar dengan pola yang tidak jelas diatas dan dibawah angka 0 dan sumbu Y, maka tidak terjadi heteroskesdastisitas.

\section{Uji pengaruh}

\section{Analisis regresi linier berganda}

Persamaan regresi linier berganda adalah sebagai berikut:

$$
\mathrm{Y}=\mathbf{a}+\mathbf{b 1 . X 1}+\mathbf{b 2 . X 2}+e
$$

Keterangan:

$\mathrm{Y} \quad=$ Variabel dependen (Turnover Intentiom)

a $\quad=$ Konstanta

$\mathrm{b} 1, \mathrm{~b} 2=$ Koefisien garis regresi

$\mathrm{X} 1, \mathrm{X} 2=$ Variabel independen (Stress kerja, Kepuasan kerja)

$e \quad=$ Error / variabel pengganggu

\section{Analisis koefisien determinasi $\left(\mathbf{R}^{2}\right)$}

Koefisien determinasi $\left(\mathrm{R}^{2}\right)$ pada intinya menjelaskan proporsi variasi dalam variabel terikat $(\mathrm{Y})$ yang dijelaskan oleh variabel bebas (lebih dari satu variabel $\mathrm{X}$ ) secara bersama-sama. $\mathrm{R}$ adalah koefisien korelasi majemuk yang mengukur tingkat 
hubungan antara variabel terikat dengan semua variabel bebas yang menjelaskan secara bersama-sama dan nilainya selalu positif.

\section{Uji hipotesis}

\section{Uji t (parsial)}

Setalah data di uji dengan program spss,kaidah pengambilan keputusan dalam pengujian ini adalah: 1).Nilai signifikan $<0,05$, maka $\mathrm{H}_{0}$ ditolak dan $\mathrm{H}_{\mathrm{a}}$ diterima, 2).Nilai signifikan $>0,05$, maka $\mathrm{H}_{0}$ diterima dan $\mathrm{H}_{a}$ ditolak

\section{Uji F}

Uji $\mathrm{F}$ digunakan untuk mengetahui tingkat signifikansi pengaruh variabelvariabel independen secara bersama-sama terhadap variabel dependen. Dasar pengambilan keputusannya adalah dengan menggunakan hasil dari nilai $\mathrm{F}$ hitung, yaitu: 1).Nilai signifikan $<0,05$, maka $\mathrm{H}_{0}$ ditolak dan $\mathrm{H}_{a}$ diterima. 2).Nilai signifikan $>0,05$, maka $\mathrm{H}_{0}$ diterima dan $\mathrm{H}_{\mathrm{a}}$ ditolak.

\section{HASIL DAN PEMBAHASAN}

Olah data pada penelitian ini didapatkan dari hasil penyebaran kuesioner kepada karyawan yang bekerja shift di kota batam yang berjumlah 96 responden. Dari data responden yang sudah terkumpul tersebut kemudian diolah menggunakan program sofware SPSS (Statistical product and Service Solution)dengan sajian data sebagai berikut:

\section{Uji validitas}

Tabel 1 menunjukkan bahwa nilai $\mathrm{r}$ hitung dari semua item pernyataan lebih besar dari 0.201 dengan perbandingan nilai $r$ hitung $>r$ tabel maka butir instrumen dalam penelitian ini dinyatakan valid dan dapat disimpulkan bahwa semua pernyataan pada penelitian ini dinyatakan valid.

Tabel 1. Uji validitas

\begin{tabular}{ccccc}
\hline Variabel & Item & Rhitung & Rtable & Keterangan \\
\hline Stres Keria & X1.1 & 0,570 & 0.201 & Valid \\
(X1) & X1.2 & 0,641 & 0.201 & Valid \\
& X1.3 & 0,713 & 0.201 & Valid \\
& X1.4 & 0,527 & 0.201 & Valid \\
& X1.5 & 0,730 & 0.201 & Valid \\
& X1.6 & 0,717 & 0.201 & Valid \\
& X1.7 & 0,759 & 0.201 & Valid \\
& X1.8 & 0,759 & 0.201 & Valid \\
& X1.10 & 0,683 & 0.201 & Valid \\
Kepuasan Kerja & X1.11 & 0,406 & 0.201 & Valid \\
(X2) & X2.1 & 0,761 & 0.201 & Valid \\
& X2.2 & 0,525 & 0.201 & Valid \\
& X2.3 & 0,825 & 0.201 & Valid \\
X2.4 & 0,615 & 0.201 & Valid \\
Turnover Intention & X2.5 & 0,704 & 0.201 & Valid \\
(Y) & Y.1 & 0,847 & 0.201 & Valid \\
& Y.2 & 0,764 & 0.201 & Valid \\
& Y.3 & 0,749 & 0.201 & Valid \\
& Y.4 & 0,825 & 0.201 & Valid \\
& & & 0.201 & Valid \\
\hline
\end{tabular}

Sumber: Data diolah, 2020 


\section{Uji reliabilitas}

Berdasarkan hasil uji reliabilitas, dapat disimpulkan bahwa item-item pernyataan pada variabel Stres Kerja memilik nilai croanbach 0,849, Kepuasan Kerja sebesar 0,721 dan Turnover Intention Sebesar 0,808 yang artinya lebih besar dari 0,6 sehingga dapat dikatakan instrument reliable.

Tabel 2.Hasil uji reliabilitas

\begin{tabular}{llll}
\hline Variabel & Cronbach'sAl & Kriteria & Keterangan \\
\hline Stres Kerja & 0,849 & $>0,6$ & Reliabel \\
Kepuasan Kerja & 0,721 & $>0,6$ & Reliabel \\
Turnover Intention & 0,808 & $>0,6$ & Reliabel \\
\hline
\end{tabular}

Sumber: Data diolah, 2020

\section{Uji normalitas}

Uji normalitas pada penelitian ini menggunakan histogram regression residual yang dapat dilihat pada gambar dibawah ini:

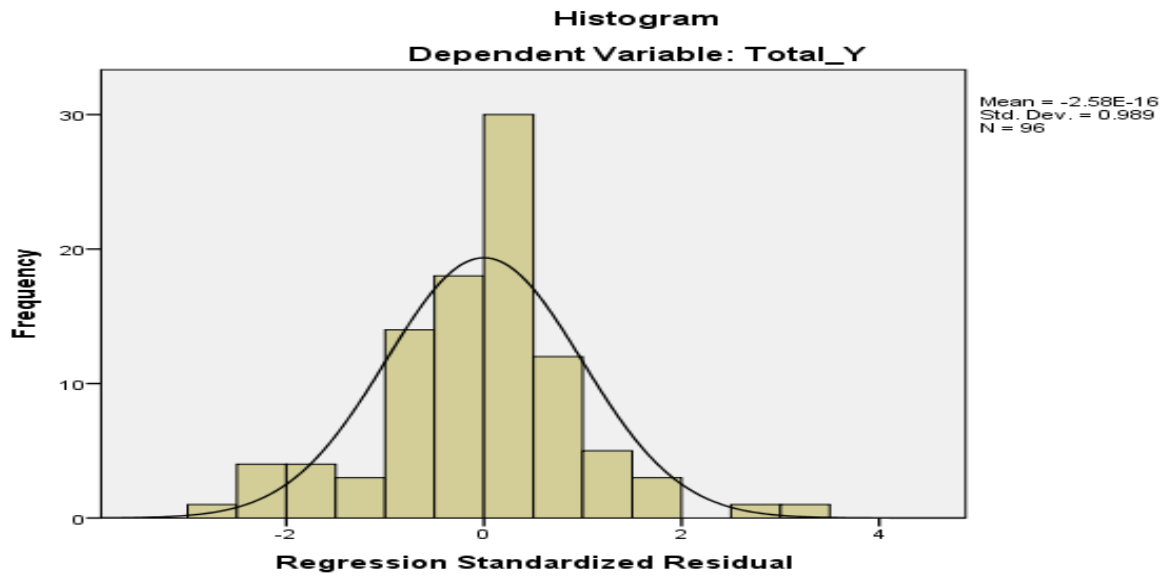

Sumber: Data diolah, 2020

Gambar 1. Histogram regression residual

Dari atas membentuk pola gambar lonceng atau bell shaped maka dapat disimpulkan bahwa data memiliki distribusi normal.

\section{Uji multikolinearitas}

Uji multikolinearitas pada penelitian ini membandingkan dengan nilai Variance Inflation Factor (VIF). Jika nilai VIF kurang dari 10, hal ini menunjukan tidak terdapat gejala multikolinieritas.

Tabel 3. Uji multikolinearitas

\begin{tabular}{llcc}
\hline & Model & \multicolumn{2}{c}{ Collinearity Statistics } \\
\cline { 2 - 3 } & Tolerance & VIF \\
\hline 1 & (Constant) & 0,911 & 1.098 \\
& Stres Kerja & 0,911 & 1.098 \\
\hline
\end{tabular}

Sumber: Data diolah, 2020 
Dari Table 3 dapat dilihat bahwa Stres kerja memiliki nilai tolerance 0,911 dan VIF 1,098 begitu juga dengan kepuasan kerja memiliki nilai tolerance sebesar 0,911 dan VIF 1,098. Nilai tolerance di atas 0,1 dan memiliki nilai VIF dibawah 10 dapat disimpulkan bahwa tidak terjadi Multikolinearitas.

\section{Uji heterokedasdisitas}

Pengujian Heteroskesdastisitas yang kedua dilakukan dengan metode grafik, yaitu dengan melihat titik-titik pada scatterplot regresi pada gambar berikut:

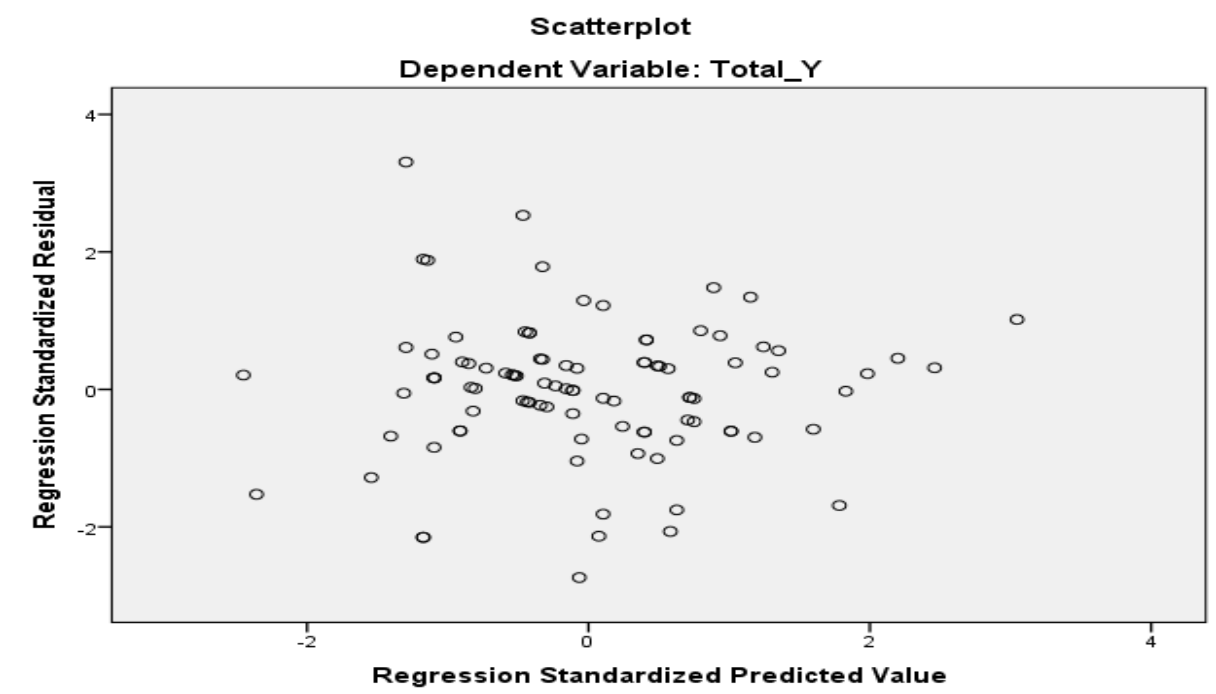

Sumber: Data diolah, 2020

Gambar 1.Scatterplot

Dari Gambar 1 menunjukkan bahwa model regresi pada penelitian ini tidak mengalamai gejala heteroskesdastisitas. Hal ini terbukti dari sebaran dataStandardized Predicted Valuepada Scatterplottitik-titik menyebar dengan pola yang tidak jelas diatas dan dibawah angka 0 dan sumbu $\mathrm{Y}$, juga menyebarsecara acak dan tidakmembentuk suatu pola tertentu yang jelas.

\section{Hasil uji regresi linear berganda}

Berdasarkan penjabaran table 4 menunjukkan persamaan regresi linear berganda sebagai berikut: $\mathrm{Y}=12.577+0,169 \mathrm{X} 1-0,289 \mathrm{X} 2+\mathrm{e}$

Tabel 4. Hasil uji regresi linear berganda

\begin{tabular}{llccccc}
\hline \multirow{2}{*}{ Model } & \multicolumn{2}{c}{$\begin{array}{c}\text { Unstandardized } \\
\text { Coefficients }\end{array}$} & $\begin{array}{c}\text { Standardized } \\
\text { Coefficients }\end{array}$ & t & Sig. \\
\cline { 2 - 4 } & \multicolumn{1}{c}{ B } & Std. Error & Beta & & \\
\hline \multirow{2}{*}{$\begin{array}{l}\text { (Constant) } \\
1\end{array}$} & Stres kerja & 12.577 & 2.830 & & 4.444 & .000 \\
& Kepuasan kerja & .169 & .048 & .339 & 3.532 & .001 \\
\hline
\end{tabular}

Sumber: Data diolah,2020 
Penjelasan dari persamaan Tabel 4 adalah: 1).Konstanta Sebesar 12.577 menunjukkan jika X1 (Stres kerja) dan X2 (Kepuasan kerja) bernilai nol, maka Y (Turnover intention) memiliki nilai sebesar 12.577. 2).Variabel X1 (Stres kerja) memiliki nilai koefisien regresi sebesar 0,169 ini berarti jika variabel bebas lainnya bernilai tetap maka setiap kenaikan 1 poin atau $1 \%$ variabel X1 (Stress kerja) akan meningkatkan Turnover Intention sebesar 0,169. 3).Variabel X2 (Kepuasan Kerja) memiliki nilai koefisien regresi sebesar -0,289 ini berarti jika variabel bebas lainnya bernilai tetap maka setiap kenaikan 1 poin atau 1\% variabel X2 (Kepuasan Kerja) akan menurunkan Turnover Intention sebesar 0,289.

\section{Uji koefesien determinasi}

Nilai koefisien determinasi $\left(\mathrm{R}^{2}\right)$ pada penelitian ini dapat dilihat pada tabel dibawah ini:

Tabel 5. Kofesien determinasi

\begin{tabular}{cccccc}
\hline Model & R & R Square & $\begin{array}{c}\text { Adjusted R } \\
\text { Square }\end{array}$ & $\begin{array}{c}\text { Std. Error of } \\
\text { the Estimate }\end{array}$ & Durbin-Watson \\
\hline 1 & $.470^{\mathrm{a}}$ & .221 & .205 & 2.966 & 1.994 \\
\hline
\end{tabular}

Sumber: Data diolah,2020

Berdasarkan Tabel 5 di atas dapat dilihat bahwa nilai R Square adalah 0,221 yang jika dipersentasikan menjadi 22,1\%. Ini menunjukkan Turnover Intention dipengaruhi oleh Stres Kerja dan Kepuasan Kerja sebesar 22,1\% sedangkan sisanya 77,9\% dipengaruhi oleh variable lain yang tidak diteliti pada penelitian ini.

\section{Uji t}

Adapun hasil dari uji t yang sudah dilakukan dapat dilihat pada penejelasan di bawah:

Tabel 6.Hasil uji t parsial

\begin{tabular}{lccccc}
\hline \multirow{2}{*}{ Model } & \multicolumn{2}{c}{$\begin{array}{c}\text { Unstandardized } \\
\text { Coefficients }\end{array}$} & $\begin{array}{c}\text { Standardized } \\
\text { Coefficients }\end{array}$ & t & Sig. \\
\cline { 2 - 4 } & B & Std. Error & Beta & & \\
\hline (Constant) & 12.577 & 2.830 & & 4.444 & .000 \\
Stres Kerja & .169 & .048 & .339 & 3.532 & .001 \\
Kepuasan Kerja & -.289 & .115 & -.241 & -2.509 & .014 \\
\hline
\end{tabular}

Sumber: Data diolah, 2020

Tabel diatas menunjukkan bahwa hasil pengujian dua variable bebas variable: 1).Stres kerja (X1) menunjukkan hasil t hitung 3.532dan nilai signifikan $0,001<0,05$ sehingga keputusan yang diambil adalah $\mathrm{H}_{0}$ ditolak dan $\mathrm{H}_{\mathrm{a}}$ diterima. Hal ini berarti bahwa Stres kerja (X1) berpengaruh secara positif dan signifikan terhadap Turnover Intention. 2).Variabel Kepuasan Kerja (X2) menunjukkan hasil t hitung -2.509 dan nilai signifikan $0,014<0,05$ sehingga keputusan yang diambil adalah $\mathrm{H}_{0}$ ditolak dan $\mathrm{H}_{\mathrm{a}}$ diterima. Hal ini berarti bahwa Kepuasan Kerja (X2) berpengaruh negatif dan signifikan terhadap Turnover Intention. 


\section{Uji F}

Hasil uji F memperlihatkan nilai F yang positif sebesar 13.213 (F hitung) >3,09 ( $F$ tabel) dan nilai probabilitas signifikansi sebesar $0,000<0,05$ sehingga $\mathrm{H}_{0}$ ditolak dan $\mathrm{H}_{\mathrm{a}}$ diterima.

Tabel 7.Hasil Uji F

\begin{tabular}{clccccc}
\multicolumn{1}{c}{ Model } & $\begin{array}{c}\text { Sum of } \\
\text { Squares }\end{array}$ & df & Mean Square & F & Sig. \\
\hline \multirow{3}{*}{1} & Regression & 232.428 & 2 & 116.214 & 13.213 & $.000^{\mathrm{b}}$ \\
& Residual & 817.978 & 93 & 8.795 & & \\
& Total & 1050.406 & 95 & & & \\
\hline
\end{tabular}

Sumber: Data diolah, 2020

\section{KESIMPULAN DAN SARAN}

\section{Kesimpulan}

Berdasarkan hasil penelitian diambil beberapa kesimpulan antara lain: 1).Stres Kerja berpengaruh positif dan signifikan terhadap Turnover Intention karyawan di Kota Batam. 2).Kepuasan Kerja berpengaruh negative dan signifikan terhadap Turnover Intention karyawan di Kota Batam. 3).Stres Kerja dan Kepuasan Kerja secara Secara Simultan berpengaruh positif dan signifikan terhadap Turnover Intention di Kota Batam.

\section{Saran}

Adapun saran yang dapat diberikan adalah: 1) Penelitian ini masih terbatas pada variabel Stres Kerja dan Kepuasan Kerja, sedangkan dilihat dari nilai R-square masih kecil artinya masih ada faktor lain yang mempengaruhi Turnover Intention, sehingga untuk penelitian selanjutnya perlu dikaji variabel lainnya. 2) Penelitian selanjutnya juga diharapkan agar bisa dilakukan pada karyawan yang berbeda jenis pekerjaan sehingga jumlah sampel yang didapatkan juga akan lebih banyak dan variatif yang tentunya dapat dikembangkan pada perbandingan hasil penelitian dari masing-masing jenis pekerjaan.

\section{DAFTAR PUSTAKA}

Javed, M., Khan, M. A,, Yasir, M., Aamir, S., \& Ahmed,K. (2014). Effect of Role Conflict, Work Life Balance and Job Stress on Turnover Intention: Evidence from Pakistan. Journal of Basic and Applied Scientific Research. 4(3),125-133

Kaswan. (2012). Manajemen Sumber Daya Manusia Untuk Keunggulan Bersaing Organisasi. Graha Ilmu: Yogyakarta

Mulyadi, D.(2015). Perilaku Organisasi dan Kepemimpinan Pelayanan (1st Ed.). Alfabeta: Bandung

Robbins, S. P., \& Judge, T. A. (2013). Organizational Behavior (15th Ed.). New Jersey: Pearson Education Inc.

Ronald, Sukwadi., \& Milkha, Meliana. (2014). Faktor-Faktor Yang Mempengaruhi Kinerja dan Turnover Intention Karyawan Usaha Kecil Menengah. Jurnal Rekayasa Sistem Industri, 3(1), 1-9 
Sopiah. (2008). Perilaku Organisasional. CV. Andi Offset: Yogyakarta

Sumarto. (2009). Meningkatkan Komitmen dan Kepuasan Untuk Menyurutkan Niat Keluar. Jurnal Manajemen dan Kewirausahaan,11(2), 116-125.

Syahronica, G. (2015). Pengaruh Kepuasan Kerja Dan Stress Kerja Terhadap Turnover Intention(Studi Pada Karyawan Departemen Surya Fantasi PT. Pembangunan Jaya Ancol, Tbk). Jurnal Ekonomi Bisnis UB, 20(1). 1-6

Tnay, T., Ekhsan, A., Othman, A., Siong, H. C., Lim, S \& Lim, O. 2013. The influences of job satisfaction and organizational commitment on turnover intention. Procedia-Social and Behavioral Sciences. 97(2013) 201- 208

Turkyilmaz, Ali., \& Ozkan, Coskun. (2009). Development of A Customer Satisfaction Index Model: An Application to The Turkish Mobile Phone Sector, Journal of Industrial Management \& Data System, 107(5), 672-687. 